\title{
Comparative feed ingestibility and digestibility in cattle and buffaloes
}

\author{
I Voicu, G Burlacu, M Nicolae, M Olteanu \\ Institute of Biology and Animal Nutrition, 8113 Balotesti, Romania
}

Ingestibility and digestibility of three types of feeds, alfalfa half-silage (first growth, flowering stage), corn silage (waxy stage) and wheat straw, were investigated comparatively in growing cattle and buffaloes.

The investigations used 4 Simmenthal steers aged 18 months and 4 young buffaloes (Bubalus indicus) aged 24 months, weighing in average 430 and $340 \mathrm{~kg}$ respectively.

During the first phase of the study, the two silages were fed "ad libitum" as monodiets ; during the second phase, a concentrate feed was added to silages in order to balance the diets as energy and protein. The concentrate feed was $35 \%$ corn for the alfalfa half-silage for both cattle and buffaloes and a mixture of corn, peas and sunflower meal (23\% of the diet) for the corn silage for both species.

Wheat straw was always given mixed with peas in order to meet the maintenance protein requirement.

Dry matter intake $\left(\mathrm{g} / \mathrm{kg}^{0.75}\right)$ of alfalfa silage given as monodiet was $81.4 \mathrm{~g}$ in cattle and
$65.7 \mathrm{~g}$ in buffaloes ; and $70.6 \mathrm{~g}$ and $52.3 \mathrm{~g}$ in cattle and buffaloes respectively, when it was given together with corn in the same diet (total diet intake 99.6 and $79.3 \mathrm{~g} / \mathrm{kg}^{0.75}$ respectively). When corn silage was given as monodiet, DM intake was $65.1 \mathrm{~g}$ in cattle and $85 \mathrm{~g}$ in buffaloes; when corn silage was given together with the concentrate feed, DM intakes were $62.4 \mathrm{~g}$ and $79 \mathrm{~g}$ respectively (total diet intake 81.8 and $102.5 \mathrm{~g} / \mathrm{kg}^{0.75}$ respectively).

Wheat straw intake was $58.5 \mathrm{~g}$ in cattle and $60.9 \mathrm{~g}$ in buffaloes and the total diet intake was 66.9 and $68.6 \mathrm{~g} / \mathrm{kg}^{0.75}$.

Large difference in nutrient digestibility between the two species were noticed when the two silages were given as part of a diet or as monodiets.

As concerns wheat straw, significant differences were noticed only in protein digestibility.

Standard deviation and comparison between means were calculated with Quattro Pro.

\begin{tabular}{|c|c|c|c|c|c|c|c|c|c|c|c|c|}
\hline \multirow[t]{3}{*}{ Feed } & \multicolumn{4}{|c|}{ Cattle } & \multicolumn{4}{|c|}{ Buffaloes } & \multirow{2}{*}{\multicolumn{4}{|c|}{$\begin{array}{l}\text { Sign. of the diff. between } \\
\text { cattle and buffaloes }\end{array}$}} \\
\hline & \multirow{2}{*}{$\begin{array}{l}\text { TDM } \\
\left({ }^{\star}\right)\end{array}$} & \multicolumn{3}{|c|}{ Digestibility (\%) } & TDM & \multicolumn{3}{|c|}{ Digestibility (\%) } & & & & \\
\hline & & DE & DCP & DCF & $\left({ }^{\star}\right)$ & DE & DCP & DCF & 1 & 2 & 3 & 4 \\
\hline A 1 & 81.4 & 65.7 & 62.1 & 56.3 & 65.7 & 67.9 & 65.4 & 59.0 & $<0.01$ & $<0.05$ & NS & $<0.05$ \\
\hline A 2 & 70.6 & 69.5 & 66.0 & 56.0 & 52.3 & 62.6 & 63.0 & 49.0 & $<0.01$ & $<0.05$ & NS & $<0.05$ \\
\hline C 1 & 65.1 & 70.2 & 53.0 & 63.0 & 85.0 & 73.6 & 55.0 & 72.5 & $<0.01$ & $<0.05$ & NS & $<0.01$ \\
\hline C 2 & 62.4 & 66.9 & 55.0 & 63.3 & 79.0 & 72.6 & 50.0 & 73.0 & $<0.01$ & $<0.05$ & $<0.05$ & $<0.01$ \\
\hline W & 58.5 & 53.6 & 33.7 & 66.2 & 60.9 & 53.0 & 47.3 & 66.6 & NS & NS & $<0.05$ & NS \\
\hline
\end{tabular}

$\overline{{ }^{*}}=\mathrm{g} / \mathrm{kg}^{0.75} ; \mathbf{1}=$ at $\mathrm{DM} \overline{\mathrm{kg}} \mathrm{k}^{0.75} ; 2=\overline{\mathrm{D}} \mathrm{DE} ; 3=\% \mathrm{DCP} ; \overline{4}=\% \mathrm{DCF} ; \mathrm{A} \mathbf{1}=$ alfalfa half-silage given as monodiet ; A 2 = alfalfa half-silage within the diet ; $C 1=$ corn silage given as monodiet ; $C 2$ = corn silage within the diet ; $W=$ wheat straw within the diet 